\title{
Gefitinib successfully administered in a lung cancer patient with leptomeningeal carcinomatosis after erlotinib-induced pneumatosis intestinalis
}

Hironori Uruga ${ }^{1,2^{*}}$, Shuhei Moriguchi ${ }^{1}$, Yui Takahashi ${ }^{1}$, Kazumasa Ogawa ${ }^{1}$, Kyoko Murase $^{1}$, Sayaka Mochizuki ${ }^{1}$, Shigeo Hanada ${ }^{1}$, Hisashi Takaya ${ }^{1}$, Atsushi Miyamoto ${ }^{1}$, Nasa Morokawa ${ }^{1}$ and Kazuma Kishi ${ }^{1,2}$

\begin{abstract}
Background: Pneumatosis intestinalis (PI) is a rare complication of chemotherapy, characterized by multiple gas accumulations within the bowel wall.

Case presentation: A 71-year-old woman with epidermal growth factor receptor (EGFR) mutation-positive lung adenocarcinoma was admitted to our hospital because of reduced consciousness. She was diagnosed as having leptomeningeal carcinomatosis (LM) using lumbar puncture. Because she could not swallow a tablet, erlotinib was administered via a feeding tube. Her state of consciousness gradually improved, but she experienced diarrhea several times a day. After 3 weeks of erlotinib therapy, PI occurred. Erlotinib was discontinued and PI was resolved after treatment with conservative therapies. Erlotinib was re-administrated and PI occurred again. After improvement of erlotinib-induced Pl, gefitinib was administered by a feeding tube and the patient did not experience PI or diarrhea. The patient survived 8 months from the diagnosis of LM.
\end{abstract}

Conclusion: $\mathrm{PI}$ is one of the side effects of erlotinib, and consecutive therapies are useful for the treatment of PI. In this patient, gefitinib was successfully administered after erlotinib-induced PI.

Keywords: Pneumatosis intestinalis, Epidermal growth factor receptor tyrosine kinase inhibitor, Leptomeningeal carcinomatosis, Non-small-cell lung cancer

\section{Background}

Pneumatosis intestinalis (PI) is a rare complication of chemotherapy including cytotoxic and molecular-targeted agents [1], and is characterized by multiple gas accumulations within the bowel wall. PI mainly occurs when gas enters the submucosal and subserosal tissue of the bowel wall with infiltration of giant cells [2]. The gas is thought to come from the intraluminal gastrointestinal system, bacterial production, or a pulmonary source [3]. Besides chemotherapy, PI is associated with various medical conditions, such as collagen-vascular diseases, lupus enteritis, infectious colitis, asthma, acquired immune deficiency

\footnotetext{
* Correspondence: uruga.hironori@gmail.com

'Department of Respiratory Medicine, Respiratory Center, Toranomon

Hospital, 2-2-2 Toranomon, Minato-ku, Tokyo 105-8470, Japan

${ }^{2}$ Okinaka Memorial Institute for Medical Research, Tokyo, Japan
}

syndrome, cystic fibrosis, hematopoietic stem cell transplantation, trauma, and steroid therapy [2-4]. Compared with cytotoxic agents, PI due to molecular-targeted agents is even rarer [1, 5-12], and only several cases have been reported in association with epidermal growth factor receptor (EGFR) tyrosine kinase inhibitors (TKIs) [1, 1317]. Here, we describe a patient with leptomeningeal carcinomatosis (LM) caused by EGFR-mutated lung adenocarcinoma who was treated with gefitinib via a feeding tube after erlotinib-induced PI.

\section{Case presentation}

A 71-year-old Japanese woman was admitted to Toranomon hospital because of reduced consciousness. She had a history of a mastectomy for right breast cancer. Eight months before admission, she came to our hospital 


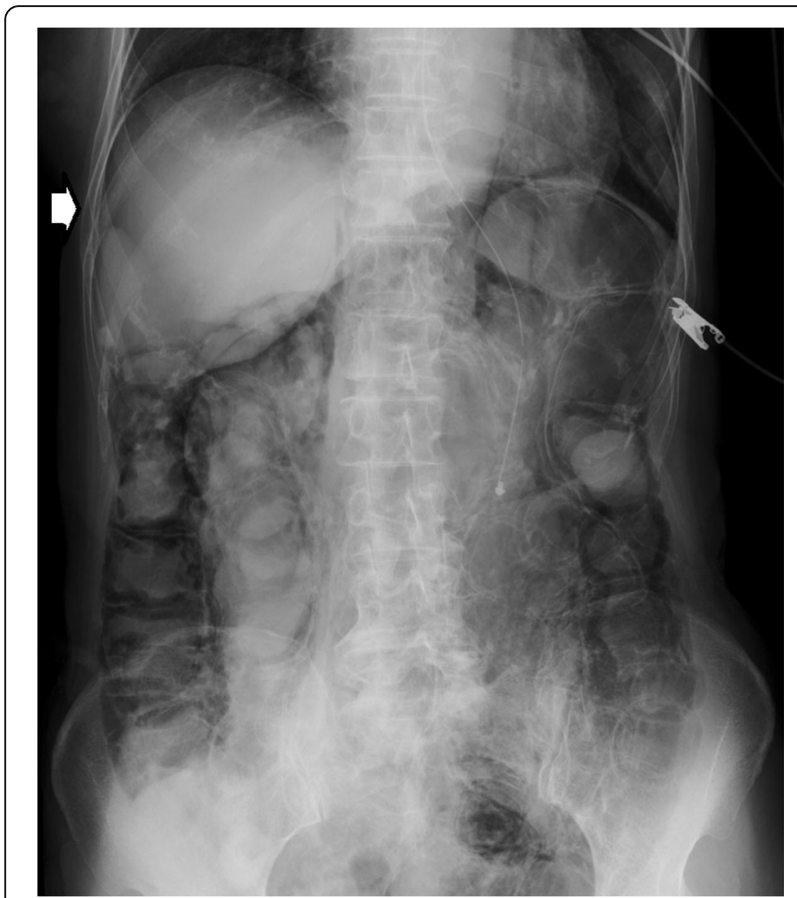

Fig. 1 An abdominal radiograph showed a dilated colon and the presence of intraluminal air along the wall of the colon with free air (arrow)

because of partial paralysis of her right hand. A chest computed tomography $(\mathrm{CT})$ scan showed a mass in the left upper lobe, as well as mediastinal and left hilar lymphadenopathy. Brain magnetic resonance imaging (MRI) showed multiple brain metastases. The patient was diagnosed with EGFR mutation-positive adenocarcinoma using transbronchial lung biopsy. She received 4 cycles of carboplatin and paclitaxel chemotherapy, and gamma knife treatment followed by whole brain radiation for brain metastases. Although chemotherapy resulted in a partial response, her state of consciousness rapidly worsened in the 2 weeks before admission. Her level of consciousness on admission was a Glasgow Come Scale (GCS) score of 8. She could not speak or move her extremities. A lumbar puncture was performed and cytological examination of her cerebrospinal fluid revealed adenocarcinoma cells. EGFR mutation analysis of cerebrospinal fluid was positive for L858R, but negative for exon $20 \mathrm{~T} 790 \mathrm{M}$. Erlotinib at $150 \mathrm{mg} /$ day was dissolved in $15 \mathrm{~mL}$ of water, and was administered via a feeding tube because she could not swallow a tablet. At the same time, $8 \mathrm{mg} /$ day dexamethasone and glycerin administration were started via drip infusion. The patient's state of consciousness gradually improved to a GCS score of 13, and serum levels of CA19-9 decreased from $3031 \mathrm{U} / \mathrm{mL}$ to $292 \mathrm{U} / \mathrm{mL}$. As a side effect of erlotinib, diarrhea of the Common Terminology Criteria for Adverse Events (CTCAE) version 4.0 grade 2 developed.
Three weeks after receiving erlotinib and steroids, the patient started to vomit and suffered from grade 3 diarrhea. At that time, her body temperature, blood pressure, and pulse rate were $36.8{ }^{\circ} \mathrm{C}, 105 / 55 \mathrm{mmHg}$ and 92 b.p.m., respectively. There was no abdominal tenderness on her physical examinations. The laboratory test results showed a normal leukocyte count $(4700 / \mathrm{mL})$, and a slightly increased C-reactive protein level $(2.4 \mathrm{mg} / \mathrm{dL})$. Arterial blood gas analysis showed alkalemia ( $\mathrm{pH} 7.50)$. An abdominal radiograph showed a dilated colon and the presence of intraluminal air along the wall of the colon (Fig. 1). A CT scan of the abdomen demonstrated pneumatosis; there was a thickening of the colon with free air, pneumoretroperitoneum, and pneumomediastinum (Fig. 2). There were no signs of bowel ischemia or portal venous air. Erlotinib and steroids were stopped, and the patient was managed conservatively with a combination of antibiotics and inhalation of oxygen. Two weeks later, the CT findings of PI were improved. Erlotinib was re-administered without steroids, and PI relapsed 4 weeks later with diarrhea. After improving PI by discontinuation of erlotinib and conservative therapies, gefitinib was administered safely without PI and

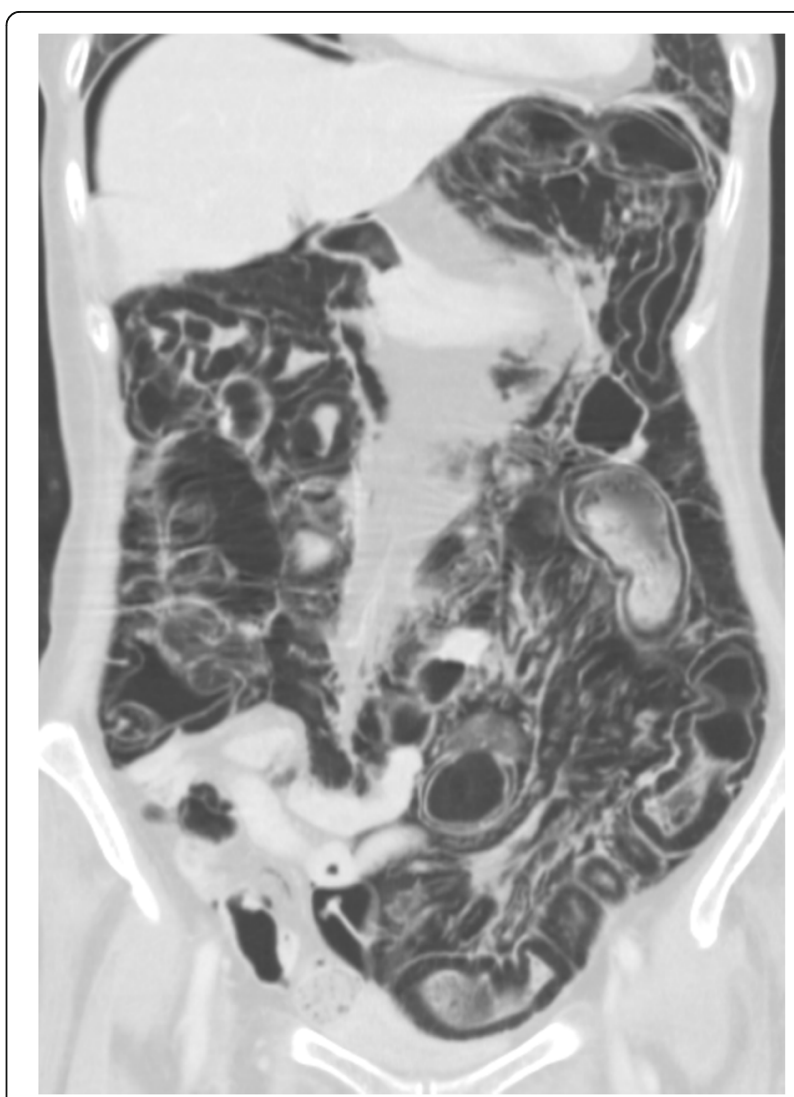

Fig. 2 A CT scan of the abdomen demonstrated a thickening of the colon with free air, pneumoretroperitoneum,

and pneumomediastinum 
Table 1 Previous case reports of pneumatosis intestinalis following gefitinib and erlotinib treatment

\begin{tabular}{|c|c|c|c|c|c|c|}
\hline Year & Author & Age & Sex & EGFR-TKIs & CT findings & Treatment \\
\hline 2012 & $\begin{array}{l}\text { Shinagare, et } \\
\text { al. 1) }\end{array}$ & N.D. & N.D. & Erlotinib & N.D. & N.D. \\
\hline 2012 & $\begin{array}{l}\text { Iwasaku, et al. } \\
\text { 13) }\end{array}$ & 82 & $\mathrm{~F}$ & Gefitinib & Intramural air within the intestinal wall & $\begin{array}{l}\text { Conservative } \\
\text { therapy }\end{array}$ \\
\hline 2012 & Lee, et al. 14) & 66 & $\mathrm{~F}$ & Gefitinib & $\begin{array}{l}\text { Intramural air within the intestinal wall, portal venous air, } \\
\text { Infarction of liver }\end{array}$ & $\begin{array}{l}\text { Conservative } \\
\text { therapy }\end{array}$ \\
\hline 2014 & $\begin{array}{l}\text { Hughes, et al. } \\
\text { 15) }\end{array}$ & $\begin{array}{l}\text { N.D. Three } \\
\text { patients }\end{array}$ & N.D. & $\begin{array}{l}\text { Erlotinib and } \\
\text { pertuzumab }\end{array}$ & N.D. & N.D. \\
\hline 2015 & $\begin{array}{l}\text { Ando, et al. } \\
\text { 16) }\end{array}$ & 71 & M & Gefitinib & Intramural air within the intestinal wall, ascites & $\begin{array}{l}\text { Conservative } \\
\text { therapy }\end{array}$ \\
\hline 2016 & $\begin{array}{l}\text { Maeda, et al. } \\
\text { 17) }\end{array}$ & 80 & $\mathrm{~F}$ & Gefitinib & Intramural air within the intestinal wall, pneumoretroperitoneum, & $\begin{array}{l}\text { Conservative } \\
\text { therapy }\end{array}$ \\
\hline 2017 & Current case & 71 & $\mathrm{~F}$ & Erlotinib & $\begin{array}{l}\text { Intramural air within the intestinal wall, pneumoretroperitoneum, } \\
\text { pneumomediastinum }\end{array}$ & $\begin{array}{l}\text { Conservative } \\
\text { therapy }\end{array}$ \\
\hline
\end{tabular}

EGFR-TKIs Epidermal growth factor receptor tyrosine kinase inhibitors

N.D Not described

diarrhea for 3 month. At that time, the EGFR-TKIs afatinib and osimertinib were available in the Japanese market. The number of cells in the cerebral fluid decreased from $132 / \mu \mathrm{L}$ to $37 / \mu \mathrm{L}$ with erlotinib and gefitinib, although the cytology was still positive for adenocarcinoma. The patient died of worsening brain metastases 8 months after the diagnosis of LM.

\section{Discussion}

We describe a patient with LM from EGFR-mutated lung adenocarcinoma who was treated with erlotinib followed by gefitinib through a feeding tube for 8 months. As adverse events of erlotinib, PI and grade 3 diarrhea developed, both of which were resolved after treatment with conservative therapies. Subsequently, gefitinib could be administered without either PI or diarrhea.

The precise mechanism by which gefitinib was administered safely instead of erlotinib in this patient is unclear. In comparison of side effects between erlotinib and gefitinib, hepatotoxicity was more common in gefitinib, but rash was more common in erlotinib; the incidence of diarrhea and interstitial lung disease was almost the same [18]. However, there have been several reports of successful treatments with erlotinib after gefitinib-induced interstitial lung disease [19-22]. One of these reports suggested the hypothesis that minor differences in the chemical structure between two drugs binding to the common quinazoline and anilino rings might influence the results [20].

PI can be caused by various agents, such as cyclophosphamide, methotrexate, vincristine, doxorubicin, daunorubicin, cytarabine, fluorouracil, paclitaxel, docetaxel, etoposide, irinotecan, 5 fluorouracil (5-FU), and cisplatin [12, 14]. PI secondary to molecular-targeted agents is very rare $[1,5-14]$. Most patients received molecular-targeted therapy alone, and were treated conservatively for PI [1]. Regarding
EGFR-TKIs, PI was reported following gefitinib and erlotinib treatment in several case reports [1, 13-17] (Table 1). These patients presented with gastrointestinal symptoms, such as diarrhea or constipation, and PI was improved by conservative therapies and discontinuation of TKIs.

The precise mechanism of PI secondary to EGFR-TKIs is unknown. EGFR-TKIs have gastrointestinal toxicities, such as diarrhea, nausea, and vomiting. Gastrointestinal toxicities and the subsequent loss of mucosal integrity of the bowel wall may contribute to PI secondary to EGFR-TKIs. In the present case, we were able to treat the patient with gefitinib and erlotinib-induced PI because she did not experience diarrhea after the switch to gefitinib.

The radiological findings of PI were first reported on abdominal radiograph, and the features were submucosal and subserosal cysts formed in ellipses/circles within the bowel wall [23]. However, nowadays, CT is more useful for the diagnosis of PI $[3,24]$. Typical CT findings are submucosal and subserosal air within the bowel wall and free air [25, 26]. Like in our patient, PI is sometimes accompanied by pneumomediastinum, which occurs when retroperitoneal and peritoneal air enters along the para-aortic tissues and exits thorough the esophageal hiatus into the mediastinum $[27,28]$.

\section{Conclusions}

PI is one of the side effects of EGFR TKIs, and is usually treated with conservative therapies. In this patient, gefitinib was successfully administered after erlotinib-induced PI.

\section{Abbreviations}

5-FU: 5 fluorouracil; CT: Computed tomography; CTCAE: Common Terminology Criteria for Adverse Events; EGFR-TKI: Epidermal growth factor receptor tyrosine kinase inhibitor; GCS: Glasgow Come Scale; LM: Leptomeningeal carcinomatosis; NSCLC: Non-small-cell lung cancer; PI: Pneumatosis intestinalis 


\section{Availability of data and materials}

Data are available on request due to privacy.

\section{Authors' contributions}

HU was substantially contributed to acquisition of data and writing the manuscript. S.M, Y.T, K.O, K.M, S.M, S.H, H.T, A.M, and N.M collected the patient's data and provided Figs. KK substantially revised the manuscript. The final version of the manuscript was seen and approved by all authors.

\section{Ethics approval and consent to participate}

Not applicable.

\section{Consent for publication}

Written informed consent for publication of this case report and associated images could not be obtained from the patient because of reduced consciousness, but the patient's husband provided written informed consent for the publication of the case report and accompanying images.

\section{Competing interests}

The authors declare that they have no competing interests.

\section{Publisher's Note}

Springer Nature remains neutral with regard to jurisdictional claims in published maps and institutional affiliations.

Received: 23 November 2017 Accepted: 13 August 2018

Published online: 16 August 2018

\section{References}

1. Shinagare AB, Howard SA, Krajewski KM, Zukotynski KA, Jagannathan JP, Ramaiya NH. Pneumatosis intestinalis and bowel perforation associated with molecular targeted therapy: an emerging problem and the role of radiologists in its management. AJR Am J Roentgenol. 2012;199(6): 1259-165

2. Koreishi A, Lauwers GY, Misdraji J. Pneumatosis intestinalis: a challenging biopsy diagnosis. Am J Surg Pathol. 2007;31(10):1469-75.

3. St Peter SD, Abbas MA, Kelly KA. The spectrum of pneumatosis intestinalis. Arch Surg. 2003;138(1):68-75

4. Suzuki HI, Izutsu K, Watanabe T, Oshima K, Kanda Y, Motokura T, et al. Lateonset pneumatosis cystoides intestinalis associated with non-infectious pulmonary complications after allogeneic hematopoietic stem cell transplantation. Int J Hematol. 2008:88(1):116-8.

5. Asmis TR, Chung KY, Teitcher JB, Kelsen DP, Shah MA. Pneumatosis intestinalis: a variant of bevacizumab related perforation possibly associated with chemotherapy related GI toxicity. Investig New Drugs. 2008;26(1):95-6.

6. Coriat R, Ropert S, Mir O, Billemont B, Chaussade S, Massault PP, et al. Pneumatosis intestinalis associated with treatment of cancer patients with the vascular growth factor receptor tyrosine kinase inhibitors sorafenib and sunitinib. Investig New Drugs. 2011;29(5):1090-3.

7. Flaig TW, Kim FJ, La Rosa FG, Breaker K, Schoen J, Russ PD. Colonic pneumatosis and intestinal perforations with sunitinib treatment for renal cell carcinoma. Investig New Drugs. 2009;27(1):83-7.

8. Jarkowski A 3rd, Hare R, Francescutti V, Wilkinson N, Khushalani N. Case report of pneumatosis intestinalis secondary to sunitinib treatment for refractory gastrointestinal stromal tumor. Anticancer Res. 2011;31(10): 3429-32.

9. Kashima T, Ohno Y, Tachibana M. Pneumatosis intestinalis and hepatic portal venous gas in a patient receiving sorafenib. Int J Urol. 2012;19(11): 1041-2

10. Vijayakanthan N, Dhamanaskar K, Stewart L, Connolly J, Leber B, Walker I, et al. A review of pneumatosis intestinalis in the setting of systemic cancer treatments, including tyrosine kinase inhibitors. Can Assoc Radiol J. 2012; 63(4):312-7.

11. Viswanathan C, Bhosale P, Ganeshan DM, Truong MT, Silverman P, Balachandran A. Imaging of complications of oncological therapy in the gastrointestinal system. In: Cancer Imaging. 2012;12:163-72.

12. Yoon S, Hong YS, Park SH, Lee JL, Kim TW. Pneumatosis intestinalis after cetuximab-containing chemotherapy for colorectal cancer. Jpn J Clin Oncol. 2011;41(10):1225-8.
13. Iwasaku M, Yoshioka H, Korogi Y, Kunimasa K, Nishiyama A, Nagai H, et al. Pneumatosis cystoides intestinalis after gefitinib therapy for pulmonary adenocarcinoma. J Thorac Oncol. 2012;7(1):257.

14. Lee JY, Han HS, Lim SN, Shim YK, Choi YH, Lee OJ, et al. Pneumatosis intestinalis and portal venous gas secondary to Gefitinib therapy for lung adenocarcinoma. BMC Cancer. 2012;12:87.

15. Hughes B, Mileshkin L, Townley P, Gitlitz B, Eaton K, Mitchell P, et al. Pertuzumab and erlotinib in patients with relapsed non-small cell lung cancer: a phase II study using 18F-fluorodeoxyglucose positron emission tomography/computed tomography imaging. Oncologist. 2014;19(2):175-6.

16. Ando T, Sakata J, Maruyama T, Hirose Y, Okabe Y, Takizawa K, et al. A Case of Pneumatosis Cystoides Intestinalis Secondary to Gefitinib Therapy for Lung Adenocarcinoma. Gan To Kagaku Ryoho. 2015;42(7):847-9. Abstract in English

17. Maeda A, Nakata M, Shimizu K, Yukawa T, Saisho S, Okita R. Pneumatosis intestinalis after gefitinib therapy for pulmonary adenocarcinoma: a case report. World J Surg Oncol. 2016:14(1):175.

18. Takeda M, Okamoto I, Nakagawa K. Pooled safety analysis of EGFR-TKI treatment for EGFR mutation-positive non-small cell lung cancer. Lung Cancer. 2015:88(1):74-9.

19. Chang SC, Chang CY, Chen CY, Yu CJ. Successful erlotinib rechallenge after gefitinib-induced acute interstitial pneumonia. J Thorac Oncol. 2010:5(7): 1105-6.

20. Takeda M, Okamoto I, Makimura C, Fukuoka M, Nakagawa K. Successful treatment with erlotinib after gefitinib-induced severe interstitial lung disease. J Thorac Oncol. 2010:5(7):1103-4.

21. Koma Y, Matsuoka H, Yoshimatsu H, Suzuki Y. Successful treatment with erlotinib after gefitinib-induced interstitial lung disease: a case report and literature review. Int J Clin Pharmacol Ther. 2012;50(10):760-4.

22. Kashiwabara K, Semba H, Fujii S, Tsumura S. Outcome in advanced nonsmall cell lung cancer patients with successful rechallenge after recovery from epidermal growth factor receptor tyrosine kinase inhibitor-induced interstitial lung disease. Cancer Chemother Pharmacol. 2017;79(4):705-10.

23. Wolfe JN, Evans WA. Gas in the portal veins of the liver in infants; a roentgenographic demonstration with postmortem anatomical correlation. Am J Roentgenol Radium Therapy, Nucl Med. 1955;74(3):486-8.

24. Lassandro F, Valente T, Rea G, Lassandro G, Golia E, Brunese L, et al. Imaging assessment and clinical significance of pneumatosis in adult patients. Radiol Med. 2015;120(1):96-104.

25. Sakurai Y, Hikichi M, Isogaki J, Furuta S, Sunagawa R, Inaba K, et al. Pneumatosis cystoides intestinalis associated with massive free air mimicking perforated diffuse peritonitis. World J Gastroenterol. 2008;14(43): 6753-6.

26. Aziret $\mathrm{M}$, Erdem $\mathrm{H}$, Ulgen $\mathrm{Y}$, Kahramanca S, Cetinkunar S, Bozkurt $\mathrm{H}$, et al. The appearance of free-air in the abdomen with related pneumatosis cystoides intestinalis: three case reports and review of the literature. Int J Surg Case Rep. 2014;5(12):909-13.

27. Honne K, Maruyama A, Onishi S, Nagashima T, Minota S. Simultaneous pneumatosis cystoides intestinalis and pneumomediastinum in a patient with systemic sclerosis. J Rheumatol. 2010;37(10):2194-5.

28. Keklik F, Cayci Z, Arndt P, Ustun C. Spontaneous complete resolution of pneumomediastinum and pneumatosis intestinalis caused by acute GVHD. Am J Hematol. 2016;91(7):749-50.

Ready to submit your research? Choose BMC and benefit from:

- fast, convenient online submission

- thorough peer review by experienced researchers in your field

- rapid publication on acceptance

- support for research data, including large and complex data types

- gold Open Access which fosters wider collaboration and increased citations

- maximum visibility for your research: over $100 \mathrm{M}$ website views per year

At BMC, research is always in progress.

Learn more biomedcentral.com/submission 